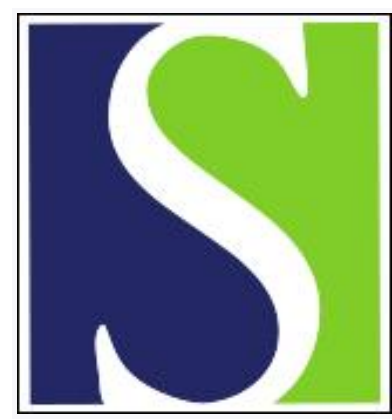

Scand J Work Environ Health 2008;34(5):327-336

https://doi.org/10.5271/sjweh.1279

Published online: 14 Oct 2008, Issue date: 00 Oct 2008

Effectiveness of interventions in preventing injuries in agriculture-a systematic review and meta-analysis

by Lehtola MM, Rautiainen RH, Day LM, Schonstein E, Suutarinen J, Salminen S, Verbeek JH

Affiliation: Finnish Institute of Occupational Health; PO BOX 93, FI-70701 Kuopio, Finland. marika.lehtola@ttl.fi

Refers to the following text of the Journal: 2003;29(4):288-296

The following articles refer to this text: 2010;36(4):269-271;

2014;40(6):649-653

Key terms: agriculture; data pooling; effectiveness; evaluation research; injury prevention; intervention; intervention study; meta-analysis; occupational accident; preventive measure; randomized controlled trial; review; systematic review

This article in PubMed: www.ncbi.nlm.nih.gov/pubmed/18853066 


\title{
Effectiveness of interventions in preventing injuries in agriculture-a systematic review and meta-analysis ${ }^{1}$
}

\author{
by Marika M Lehtola, MSc, ${ }^{2}$ Risto H Rautiainen, PhD, ${ }^{3}$ Lesley M Day, PhD, ${ }^{4}$ Eva Schonstein, PhD, ${ }^{5}$ Juha \\ Suutarinen, PhD, ${ }^{6}$ Simo Salminen, PhD, ${ }^{7}$ Jos H Verbeek, PhD²
}

\begin{abstract}
Lehtola MM, Rautiainen RH, Day LM, Schonstein E, Suutarinen J, Salminen S, Verbeek JH. Effectiveness of interventions in preventing injuries in agriculture-a systematic review and meta-analysis. Scand J Work Environ Health 2008;34(5):327-336.
\end{abstract}

\begin{abstract}
Objectives This study reviewed the effectiveness of interventions in preventing occupational injuries among workers in agriculture.

Methods Randomized controlled trials, controlled before-after studies, and interrupted time-series studies assessing interventions aimed at preventing injuries among workers in agriculture were considered. MEDLINE and five other databases were searched up to June 2006. Two authors independently assessed the eligibility of studies and the methodological quality of the ones included. Randomized controlled trials were combined in a meta-analysis. Interrupted time-series studies were reanalyzed to assess the immediate and progressive effect on injuries.

Results Five randomized controlled trials and three interrupted time-series studies met the inclusion criteria. Six studies evaluated educational interventions and financial incentives, and two studies evaluated the effect of legislation. Three randomized controlled trials on educational interventions with 4670 adult participants did not indicate any injury-reducing effect, with a rate ratio of 1.02 (95\% confidence interval $0.87-1.20)$, nor did two randomized controlled trials among children (6895 participants). Financial incentives decreased the injury level immediately after the intervention in one interrupted time-series study. Banning endosulfan pesticide in Sri Lanka led to a significant decrease in the trend of poisonings over time. Legislation requiring rollover protective structures on all tractors in Sweden did not produce a reduction in injuries, but the same requirement for new tractors was associated with a decrease in fatal injuries.

Conclusions The reviewed studies provided no evidence that educational interventions are effective in decreasing injury rates among agricultural workers. Financial incentives may be a better means of reducing injury rates. Banning highly toxic pesticides may be effective. Legislation on safety devices on tractors yielded contradictory results.
\end{abstract}

Key terms data pooling; evaluation research; intervention study; occupational accident; preventive measure, randomized controlled trial; systematic review.

About half of the world's labor force works in agriculture (1.3 billion people). The agricultural population is distributed as follows: Asia (76\%), Central America and the Caribbean (1.3\%), Europe (2.2\%), the Middle East and North Africa (3.8\%), North America (0.2\%), Oceania $(0.2 \%)$, South America (2.0\%), and Sub-Saharan Africa $(14 \%)$ (1). While the political, economic, climatic, and work conditions vary, agriculture consistently ranks

This review was adapted from the original Cochrane Review, entitled "Interventions for Preventing Injuries in the Agricultural Industry", by RH Rautiainen, MM Lehtola, LM Day, E Schonstein, J Suutarinen, S Salminen, and J Verbeek, published in The Cochrane Database of Systematic Reviews 2008, Issue 1, Art No: CD006398. DOI:10.1002/14651858. CD006398.pub2. Copyright the Cochrane Collaboration, reproduced with permission.

2 Finnish Institute of Occupational Health, Cochrane Occupational Health Field, Kuopio, Finland.

3 The University of Iowa, Iowa City, Iowa, United States.

4 Monash University, Victoria, Australia.

5 The University of Sydney, Lidcombe, New South Wales, Australia.

$6 \quad$ MTT Agrifood Research Finland, Helsinki, Finland.

7 Finnish Institute of Occupational Health, Helsinki, Finland.

Correspondence to: Marika M Lehtola; Finnish Institute of Occupational Health; PO BOX 93, FI-70701 Kuopio, Finland. [E-mail: marika.lehtola@ttl.fi] 
among the most hazardous industries, along with mining and construction (2).

Agricultural injuries are well documented in industrialized countries, but less so in developing countries. An estimated 170000 farm workers are killed each year, and millions more are either seriously injured in workplace accidents or poisoned with pesticides and other agrichemicals. It is likely that under-reporting is common, and the actual numbers are even higher (3).

Although a wide range of interventions has been developed, their effectiveness is not well understood. The most recent review of 25 farm safety interventions published in 2000 found little evidence that farm safety programs have been effective (4). While some studies have been able to report at least temporary changes in knowledge, attitudes, and behavior, none showed a sustained decrease in injuries or illnesses. Therefore, we conducted a systematic review to update and summarize the evidence on the effectiveness of interventions in preventing occupational injuries among agricultural workers.

\section{Material and methods}

\section{Inclusion criteria}

Studies had to meet the following three criteria to be included in the review: (i) the study participants had to be workers in the agricultural industry, workers primarily engaged in growing crops and animal production, (ii) fatal or nonfatal injuries had to be reported as an outcome measure, and (iii) the study design had to be a randomized controlled trial, a cluster randomized controlled trial, or a controlled before-after study, or have had an interrupted time series.

\section{Data search}

Our search terms covered the inclusion criteria for "agricultural work", "injury and safety", and "study design". The detailed search strategies have been given elsewhere (5). The following six general databases were searched through June 2006: the Cochrane Central Register of Controlled Trials, the Cochrane Injuries Group's specialized register, MEDLINE (from 1966), EMBASE (from 1988), PsychINFO (from 1983), and OSH-ROM (including NIOSHTIC and HSELINE). In addition, we searched seven agriculture-specific databases and three websites. Studies in any language were considered for inclusion.

\section{Study selection, data extraction and quality assessment}

Two researchers (ML and RR) independently screened the obtained titles and abstracts for eligibility, extracted data using a standardized form, and assessed the quality of the studies that met the inclusion criteria. The researchers were excluded from assessing their own studies. Articles in languages other than English were reviewed by a native speaker. The methodological quality of the randomized controlled trials and interrupted time-series studies was assessed according to Downs \& Black (6) and Ramsay et al (7), respectively. Missing data were requested from authors and received in all but two cases $(8,9)$.

\section{Quantitative data analysis}

The intervention effect of the randomized controlled trials and the cluster randomized controlled trials was recalculated if necessary as the ratio of injury rates per 100 person-years of the intervention and the control groups. Similar interventions addressing either adults or children were combined using the natural logarithms of the rate ratios and the generic inverse variance method as implemented in RevMan 4.2 (The Cochrane Centre, The Cochrane Collaboration, Copenhagen, Denmark, 2002) and described in the Cochrane Handbook of Systematic Reviews of Interventions (10). To facilitate the interpretation, we converted the pooled effect size and its confidence intervals back into a pooled rate ratio.

In the case of the cluster randomized controlled trials in which the clustering effect was not taken into account (11), we calculated the "effective sample size" by dividing the original sample size with the design effect, as described in the Cochrane Handbook (10).

For the interrupted time-series studies, the outcomes were reanalyzed according to Ramsay et al $(7,12)$ and Vidanapathirana (13). These methods utilize a segmented time-series regression analysis to estimate the effect of an intervention while taking into account secular time trends and any autocorrelation between individual observations. These reanalyses were performed with Stata 9.2 for Windows (StataCorp LP, College Station, TX, USA). The reanalysis made it possible to estimate the change in level and the change in trend after the intervention (7). A change in level, an immediate intervention effect, was defined as the difference between the observed level at the first intervention time point and that predicted by the pre-intervention time trend. A change in trend, a sustained effect of the intervention, was defined as the difference between the post- and pre-intervention slopes. For similar comparisons, we performed a meta-analysis separately for the changes in level and for the changes in trend, as recommended by Ramsay et al (12), using the generic inverse variance method as implemented in RevMan 4.2.

The Springfeldt interrupted time-series study (14) included the following four different years in which legislation was introduced: 1959 (A), 1965 (B), 1970 (C), and 1981 (D). The data were divided into the 
following four different time series surrounding these interventions: 1957-1964, 1960-1969, 1966-1975, and 1974-1990. To prevent including the same data twice in the meta-analysis, we combined the introduction of legislation related to new tractors [requiring rollover protective structures in 1959 (A) and safety cabins in 1970 (C)] on one hand and that related to all tractors [requiring rollover protective structures in 1965 (B) and cabins in 1981(D)] on the other.

\section{Results}

\section{Study selection}

The references retrieved from the six main databases $(\mathrm{N}=7822)$ and the topic-related databases and websites $(\mathrm{N}=794)$ totaled 8616 . From these, 122 potential full articles were selected. During the process of reviewing these articles, 10 new references were identified from the reference lists, the total number of references therefore being 132 articles. From the 132 articles, 7 could not be retrieved after an intensive search, 3 were reports concerning the same study, and 114 did not meet the inclusion criteria. Consequently we included 8 studies in the review [3 randomized controlled trials $(8,15,16), 2$ cluster randomized controlled trials $(9,11)$, and 3 interrupted time-series studies $(14,17,18)]$. After a recheck of the missing titles, it did not appear that we missed any important studies.

\section{Study characteristics}

Three of the aforementioned studies were from the United States $(8,9,16)$, two came from Finland (11, 17 ), and one came from each of the following countries: Denmark (15), Sweden (14), and Sri Lanka (18) (table 1). All of the studies were published between 1993 and 2006, and the interventions were carried out during 1959-2003.

Two studies $(8,9)$ examined injury prevention among children or adolescents. The rest dealt with injury prevention among adults, and one of these (11) had only male reindeer herders as its participants.

All of the randomized controlled trials included a combination of the following educational interventions (table 2): (i) personal education by occupational health and safety (OHS) professionals (eg, about farm safety checks, health checks, or safety courses), (ii) personal education by non-OHS professionals, including other participants (eg, farm visits or group discussions), (iii) written information (eg, booklets, guides, mailings, written reports, booster interventions), and (iv) financial incentives (eg, travel expenses reimbursed or money paid to a participating farm).
Lee et al (9) combined all four of the aforementioned elements. Two studies $(15,16)$ combined three of the elements, one study (8) used two, and one (11) contained only one of the elements. Two studies had two intervention groups and a control group $(9,11)$. We used the most extensive intervention in the meta-analysis.

The interrupted time-series study of Rautiainen (17) was based solely on incentives, studying how insurance premium discounts affect injury claims. Another interrupted time-series study (18) evaluated pesticide regulation banning endosulfan use to decrease fatal poisonings. Springfeldt (14) evaluated the effect of regulations requiring safety devices (technical measures) on tractors.

\section{Methodological quality of the included studies}

None of the studies attempted to blind its study participants, since blinding is difficult to accomplish in these types of studies. Only one study (8) reported blinding those who measured the outcome. Other issues decreasing the internal validity scores included noncompliance, unclear randomization, and no adequate adjustment for confounding. The maximum and minimum internal validity scores of the randomized controlled trials were 8 and 5 points, respectively, out of 13 points (table 3 ).

The quality of the three interrupted time-series studies were rated as follows: one study (17) received 5 out of the maximum 8 points, and the other two studies (14, 18 ) received only 3 points. The most common problem was the use of inappropriate time-series techniques for the analysis or no statistical analysis at all.

\section{Effectiveness of educational interventions on injuries \\ Randomized controlled trials}

A meta-analysis of three randomized controlled trials $(11,15,16)$ aimed at reducing injuries among adults showed no evidence of an effect on injuries [rate ratio $1.02,95 \%$ confidence interval (95\% CI) $0.87-1.20$ ] (figure 1). The narrow $95 \%$ confidence interval indicated that a more positive or more negative outcome is not very likely for these kinds of educational interventions. The studies were statistically homogeneous.

The two randomized controlled trials $(8,9)$ aimed at reducing injuries among children and adolescents did not show a significant effect either, with a rate ratio of 1.27 (95\% CI 0.51-3.16) (figure 2). However, heterogeneity was high $\left(\mathrm{I}^{2}=91.8 \%\right)$, as one study had a significant effect in favor of the control group.

\section{Interrupted time-series studies}

In one interrupted time-series study (17), there was evidence that incentives have an immediate injury-reducing 
Table 1. Characteristics of the included studies. (cRCT = cluster randomized controlled trial, FFA = Future Farmers of America; FTE = full-time equivalent, ITS = interrupted time-series, MATA = employment accident insurance for Finnish farmers, NAGCAT = the North American Guidelines for Children's Agricultural Tasks, RCT = randomized controlled trial)

\begin{tabular}{|c|c|c|c|c|c|}
\hline Study & $\begin{array}{l}\text { Study } \\
\text { design }\end{array}$ & Participants & $\begin{array}{l}\text { Intervention, form of intervention, imple- } \\
\text { mentation year and country }\end{array}$ & Outcomes & Notes \\
\hline $\begin{array}{l}\text { Ga- } \\
\text { dom- } \\
\text { ski et al, } \\
2006 \text { (8) }\end{array}$ & RCT & $\begin{array}{l}\text { Farm families, } \\
462 \text { intervention } \\
\text { farms and } 469 \\
\text { control farms }\end{array}$ & $\begin{array}{l}\text { 1. NAGCAT guideline implementation and } \\
\text { booster interventions issued in } 2001 \text { in the } \\
\text { United States } \\
\text { 2. Control group (no intervention) } \\
\text { Form: education and behavior (incentives) }\end{array}$ & $\begin{array}{l}\text { Primary: injuries of children per } 100 \\
\text { full-time equivalents } \\
\text { Secondary: NAGCAT-related and } \\
\text { NAGCAT-preventable injuries, violations } \\
\text { of NAGCAT age guidelines (adoption of } \\
\text { safety change, behavior) }\end{array}$ & $\begin{array}{l}\text { Injury definition: any condi- } \\
\text { tion occurring on the farm } \\
\text { that resulted in at least } 4 \\
\text { hours of restricted activity or } \\
\text { required professional medi- } \\
\text { cal treatment }\end{array}$ \\
\hline $\begin{array}{l}\text { Lee et al, } \\
2004(9)\end{array}$ & $\mathrm{cRCT}$ & $\begin{array}{l}\text { Students in } 123 \\
\text { FFA chapters, } \\
41 \text { chapters in }\end{array}$ & $\begin{array}{l}\text { 1. Partners program implemented in 1998- } \\
2000 \text { in the United States: training of FFA } \\
\text { advisors and student team members, learn- }\end{array}$ & $\begin{array}{l}\text { Primary: accidents } \\
\text { Secondary: safety knowledge } \\
\text { (awareness) }\end{array}$ & $\begin{array}{l}\text { Injury definition: not } \\
\text { reported }\end{array}$ \\
\hline
\end{tabular}

each; standard, ing material, conventions, and news

enhanced and 2. Second enhanced intervention group:

control group in addition to point 1 this group got more mailings, phone contact with program facilitator, contact opportunity with local public health office with a USD 300 incentive and free personal protection supplies

3. Control group: no intervention except the same national program marketing material as the other groups

Form: education and behavior (incentives)

Pekkar- cRCT Reindeer herd- 1. Information dissemination by theme letinen et ers in 53 herd- ters in 1986 in northern Finland

al, 1994

(11) ing districts (to- 2. Information dissemination during tal of 324 men); cal examinations conducted in 1986 intervention $A \quad 3$. Control group (no intervention), had had 18 districts access to information about the study in $(\mathrm{N}=1157)$ and the press

intervention Form: education and behavior (incentives)

Primary: accidents per 1000 workdays Secondary: number of applied preventive measures (adoption of safety change)
Injury definition: not clearly reported; injuries defined broadly as "all accidents", which also included minor injuries
$B$ had 17 districts $\mathrm{N}=1065$; control group had 18 districts $(\mathrm{N}=1102)$

Farm or worker 1. Safety checks on farms, 1-day course or farm family, issued between November 1995 and July 208 farms with 1997 in Denmark each interven- Form: education and behavior (incentives) tion and control group
Rasmus- RCT sen et al, 2003 (15)
104 farms in 2. Control group (no intervention)

Primary: (all) injuries per 100000 work- Injury definition: a sudden, hours (risk time adjusted for seasonal workhours (no adjustment), medically treated injuries per 100000 workhours use of personal protective equipment

\section{Primary: all injuries per 100}

Farm or worker 1. Certified safe farm program impleor farm family, mented in 1999-2003 in the United States: 169 intervention health screenings, on-farm safety reviews, farms and 187 educational element and incentive of USD control farms 200 each year 2. Control group: no intervention, but received a USD 75 compensation payment Form: education and behavior (incentives)

al, 2004

Secondary: injuries with at least 1 day years, injuries resulting in at least USD

Rautiai- ITS Finnish farmnen, based on ers belonging

20056 years to mandatory

1. Insurance premium discount program issued in July 1997 in Finland, 10\% reduc(17) before and 6 years MATA insurance up to $50 \%$ after 5 claim-free years system, 224280 2. No control group persons in 1990 Form: education and behavior (incentives) after an and 109997 interven- persons in 2003 tion variation)

Secondary: (all) injuries per 100000 (seasonal variation adjusted and unadjusted risk time), time at risk, safety scores (adoption of safety change), (behavior) erson-years of disability per 100 person-years, injuries with at least 1 visit for professiona care per 100 person-years, injuries requiring hospital care per 100 person100 costs per 100 person-years, injuries for which some costs were covered by insurance per 100 person-years, injury characteristics, costs unintended incident that occurs during the performance or supervision of farm work and results in personal injury; injuries recorded that received professional treatment and accidents resulting in an injury requiring a break from work of less than or respectively, more than 10 minutes; minor scrapes and bruises not recorded

Injury definition: an event that is sudden, unexpected unintentional, has an external cause, occurs during farm work, and results in bodily harm and some loss of worktime, loss of consciousness, or considerable pain or discomfort; d $85 \%$ minimum safety score required for becoming certified, but lower-scoring intervention farms also included in the analysis

Primary: injury insurance claims: injury Injury definition (MATA): a sudden unexpected forceful event with external cause which results in bodily damage or an ailment and which occurs in the course of agricultural work; occupational diseases and back injuries excluded 
Table 1. Continued.

\begin{tabular}{|c|c|c|c|c|c|}
\hline Study & $\begin{array}{l}\text { Study } \\
\text { design }\end{array}$ & Participants & $\begin{array}{l}\text { Intervention, form of intervention, imple- } \\
\text { mentation year and country }\end{array}$ & Outcomes & Notes \\
\hline $\begin{array}{l}\text { Roberts } \\
\text { et al, } \\
2003 \\
(18)\end{array}$ & $\begin{array}{l}\text { ITS, } \\
\text { based on } \\
7 \text { years } \\
\text { before } \\
\text { and } 3 \\
\text { years } \\
\text { after an } \\
\text { interven- } \\
\text { tion }\end{array}$ & $\begin{array}{l}\text { Farmers or } \\
\text { society in the } \\
\text { Anuradhapura } \\
\text { district }\end{array}$ & $\begin{array}{l}\text { 1. Endosulfan banned in } 1998 \text { in Sri Lanka } \\
\text { 2. No control group } \\
\text { Form: legislation and enforcement }\end{array}$ & $\begin{array}{l}\text { Primary: fatal endosulfan poisonings } \\
\text { Secondary: hospital admissions related } \\
\text { to poisonings, case fatality proportions }\end{array}$ & $\begin{array}{l}\text { The article did not report } \\
\text { whether the poisonings were } \\
\text { intentional or unintentional } \\
\text { and work-related or nonwork } \\
\text { related }\end{array}$ \\
\hline $\begin{array}{l}\text { Spring- } \\
\text { feldt, } \\
1993 \\
\text { (14) A }\end{array}$ & $\begin{array}{l}\text { ITS a, } \\
\text { based on } \\
\text { data from } \\
1957 \text { to } \\
1964\end{array}$ & $\begin{array}{l}\text { All farms or } \\
\text { workers with } \\
\text { tractors }\end{array}$ & $\begin{array}{l}\text { 1. Rollover protective structures required } \\
\text { on new tractors in } 1959 \text { in Sweden } \\
\text { 2. No control group } \\
\text { Form: legislation and enforcement }\end{array}$ & $\begin{array}{l}\text { Primary: annual total rollover injuries } \\
\text { per } 100000 \text { farm tractors } \\
\text { Secondary: annual fatal rollover injuries } \\
\text { per } 100000 \text { farm tractors, annual total } \\
\text { and fatal rollover injuries per farm trac- } \\
\text { tors or all tractors, annual total and fatal } \\
\text { rollover injuries per } 100000 \text { tractors, } \\
\text { annual rollover injuries per } 100 \text { million } \\
\text { driving hours }\end{array}$ & $\begin{array}{l}\text { Injury definition: not clearly } \\
\text { reported (fatal tractor over- } \\
\text { turn injury; nonfatal tractor } \\
\text { overturn injury); the number } \\
\text { of farmers decreased by } \\
65 \% \text { between } 1951 \text { and } \\
1981\end{array}$ \\
\hline $\begin{array}{l}\text { Spring- } \\
\text { feldt, } \\
1993 \\
(14) \text { B }\end{array}$ & $\begin{array}{l}\text { ITS a, } \\
\text { based on } \\
\text { data from } \\
1960 \text { to } \\
1969\end{array}$ & $\begin{array}{l}\text { All farms or } \\
\text { workers with } \\
\text { tractors }\end{array}$ & $\begin{array}{l}\text { 1. Rollover protective structures required } \\
\text { for employee-operated tractors, issued in } \\
1965 \text { in Sweden } \\
\text { 2. No control group } \\
\text { Form: legislation and enforcement }\end{array}$ & $\begin{array}{l}\text { Primary: annual total rollover injuries } \\
\text { per } 100000 \text { farm tractors } \\
\text { Secondary: annual fatal rollover injuries } \\
\text { per } 100000 \text { farm tractors, annual total } \\
\text { and fatal rollover injuries per farm trac- } \\
\text { tors or all tractors, annual total and fatal } \\
\text { rollover injuries per } 100000 \text { tractors, } \\
\text { annual rollover injuries per } 100 \text { million } \\
\text { driving hours }\end{array}$ & $\begin{array}{l}\text { Injury definition: not clearly } \\
\text { reported (fatal tractor over- } \\
\text { turn injury; nonfatal tractor } \\
\text { overturn injury); the number } \\
\text { of farmers decreased by } \\
65 \% \text { between } 1951 \text { and } \\
1981\end{array}$ \\
\hline $\begin{array}{l}\text { Spring- } \\
\text { feldt, } \\
1993 \\
(14) \text { C }\end{array}$ & $\begin{array}{l}\text { ITS a, } \\
\text { based on } \\
\text { data from } \\
1966 \text { to } \\
1982\end{array}$ & $\begin{array}{l}\text { All farms or } \\
\text { workers with } \\
\text { tractors }\end{array}$ & $\begin{array}{l}\text { 1. Safety cab required on all new tractors } \\
\text { sold since } 1970 \text { in Sweden } \\
\text { 2. No control group } \\
\text { Form: legislation and enforcement }\end{array}$ & $\begin{array}{l}\text { Primary: annual total rollover injuries } \\
\text { per } 100000 \text { farm tractors } \\
\text { Secondary: annual fatal rollover injuries } \\
\text { per } 100000 \text { farm tractors, annual total } \\
\text { and fatal rollover injuries per farm trac- } \\
\text { tors or all tractors, annual total and fatal } \\
\text { rollover injuries per } 100000 \text { tractors, } \\
\text { annual rollover injuries per } 100 \text { million } \\
\text { driving hours }\end{array}$ & $\begin{array}{l}\text { Injury definition: not clearly } \\
\text { reported (fatal tractor over- } \\
\text { turn injury; nonfatal tractor } \\
\text { overturn injury) }\end{array}$ \\
\hline $\begin{array}{l}\text { Spring- } \\
\text { feldt, } \\
1993 \\
(14) D\end{array}$ & $\begin{array}{l}\text { ITS a, } \\
\text { based on } \\
\text { data from } \\
1974 \text { to } \\
1990\end{array}$ & $\begin{array}{l}\text { All farms or } \\
\text { workers with } \\
\text { tractors }\end{array}$ & $\begin{array}{l}\text { 1. Safety cab on all tractors used for occu- } \\
\text { pational work, issued in } 1983 \text { in Sweden } \\
\text { 2. No control group } \\
\text { Form: legislation and enforcement }\end{array}$ & $\begin{array}{l}\text { Primary: annual total rollover injuries } \\
\text { per } 100000 \text { farm tractors } \\
\text { Secondary: annual fatal rollover injuries } \\
\text { per } 100000 \text { farm tractors, annual total } \\
\text { and fatal rollover injuries per farm trac- } \\
\text { tors or all tractors, annual total and fatal } \\
\text { rollover injuries per } 100000 \text { tractors, } \\
\text { annual rollover injuries per } 100 \text { million } \\
\text { driving hours }\end{array}$ & $\begin{array}{l}\text { Injury definition: not clearly } \\
\text { reported (fatal tractor over- } \\
\text { turn injury; nonfatal tractor } \\
\text { overturn injury) }\end{array}$ \\
\hline
\end{tabular}

a Different parts of the same ITS study used for different interventions.

effect (effect size -2.68, 95\% CI -3.80--1.56). After the intervention, there was no further decrease [ie, no significant progressive effect (effect size $-0.22,95 \% \mathrm{CI}$ -0.47-0.03)] (17) (table 4).

\section{Effectiveness of legislative interventions on injuries}

\section{Legislation banning the use of endosulfan}

In one interrupted time-series study (18), there was evidence that an endosulfan ban had a progressive effect on the reduction of fatal injuries by poisoning. There was an increasing pre-intervention injury rate over time, as indicated by the positive slope (table 4). The immediate effect was also significantly positive, meaning that the number of injuries continued to increase right after the intervention (effect size 2.20, 95\% CI 0.97-3.43).
However, there was a significant progressive effect of reducing injury occurrence (effect size $-2.15,95 \% \mathrm{CI}$ $-2.64--1.66)$ after the intervention.

\section{Legislation requiring technical measures on tractors}

Technical measures on new tractors. In the meta-analysis of the time series dealing with the introduction of legislation requiring rollover protective structures or safety cabins on new tractors, there was a significant immediate and progressive increase in all injuries, but also an immediate and progressive decrease in fatal injuries with respective effect sizes of $-0.90(95 \% \mathrm{CI}-3.38-1.58)$ and -0.93 (95\% CI -1.82--0.03) (14).

Technical measures for all tractors. In the meta-analysis of the time series of the introduction of legislation 
Table 2. Components of the educational intervention studies. (FFA = future farmers of America)

\begin{tabular}{|c|c|c|c|c|c|}
\hline Study & Participants & $\begin{array}{l}\text { Occupational health and } \\
\text { safety professionals } \\
\text { involved }\end{array}$ & $\begin{array}{l}\text { No occupational health and safe- } \\
\text { ty professionals involved }\end{array}$ & & Financial incentive \\
\hline $\begin{array}{l}\text { Ga- } \\
\text { doms- } \\
\text { ki et al, } \\
2006 \\
\text { (8) }\end{array}$ & Farm parents & . & $\begin{array}{l}\text { One farm visit by a lay educator } \\
\text { with farming background }\end{array}$ & $\begin{array}{l}\text { Booklet of } 52 \text { guidelines; booster inter- } \\
\text { ventions (postcard, calendar, refrigera- } \\
\text { tor magnet) }\end{array}$ & $\cdot$ \\
\hline $\begin{array}{l}\text { Lee } \\
\text { et al, } \\
2004 \\
\text { (9) A }\end{array}$ & $\begin{array}{l}\text { FFA chapters, } \\
\text { students } \\
\text { (selected for } \\
\text { meta-analy- } \\
\text { sis) }{ }^{a}\end{array}$ & $\begin{array}{l}\text { One interactive 4-hour } \\
\text { training of FFA advisers } \\
\text { and student team mem- } \\
\text { bers; personal contact } \\
\text { with local public health } \\
\text { office; community nurse } \\
\text { involvement in program } \\
\text { activities }\end{array}$ & $\begin{array}{l}\text { Encouragement to implement } \\
\text { program from local agribusi- } \\
\text { nesses; opportunity to discuss } \\
\text { activities at national FFA conven- } \\
\text { tions; bi-weekly phone contact } \\
\text { with program facilitator }\end{array}$ & $\begin{array}{l}\text { Instruction guides; "treasure chest"; } \\
\text { highlight of local health and safety } \\
\text { events in national newsletter; quarterly } \\
\text { mailings of topic-specific guides; free } \\
\text { personal protection supplies }\end{array}$ & $\begin{array}{l}\text { Training travel expenses re- } \\
\text { imbursed; USD } 300 \text { incentive } \\
\text { for community nurse involve- } \\
\text { ment in program activities }\end{array}$ \\
\hline $\begin{array}{l}\text { Lee } \\
\text { et al, } \\
2004 \\
\text { (9) B }\end{array}$ & $\begin{array}{l}\text { FFA chapters, } \\
\text { students }\end{array}$ & $\begin{array}{l}\text { One interactive 4-hour } \\
\text { training of FFA advisers } \\
\text { and student team mem- } \\
\text { bers; one "refresher" } \\
\text { on-site in-person train- } \\
\text { ing session on the } \\
\text { implementation of the } \\
\text { program }\end{array}$ & $\begin{array}{l}\text { Encouragement to implement } \\
\text { program from local agribusi- } \\
\text { nesses; opportunity to dis- } \\
\text { cuss activities at national FFA } \\
\text { conventions }\end{array}$ & $\begin{array}{l}\text { Instruction guides; "treasure chest"; } \\
\text { highlight of local health and safety } \\
\text { events in national newsletter }\end{array}$ & $\begin{array}{l}\text { Training travel expenses } \\
\text { reimbursed }\end{array}$ \\
\hline $\begin{array}{l}\text { Pekka- } \\
\text { rinen } \\
\text { et al, } \\
1994 \\
\text { (11) A }\end{array}$ & $\begin{array}{l}\text { Reindeer herd- } \\
\text { ers (selected } \\
\text { for meta-anal- } \\
\text { ysis) a }\end{array}$ & $\begin{array}{l}\text { Occupational health } \\
\text { personnel informed } \\
\text { herders during medi- } \\
\text { cal examinations about } \\
\text { accident prevention; } \\
\text { focus on personal pro- } \\
\text { tection equipment and } \\
\text { ergonomics }\end{array}$ & . & . & . \\
\hline $\begin{array}{l}\text { Pekka- } \\
\text { rinen } \\
\text { et al, } \\
1994 \\
\text { (11) B }\end{array}$ & $\begin{array}{l}\text { Reindeer } \\
\text { herders }\end{array}$ & & $\begin{array}{l}\text { Leaders of the district and } \\
\text { contact persons received eight } \\
\text { theme letters and were asked } \\
\text { to inform herders in their own } \\
\text { districts }\end{array}$ & $\begin{array}{l}\text { Eight "theme" letters during } 1 \text { year de- } \\
\text { scribing } 34 \text { preventive measures. }\end{array}$ & . \\
\hline $\begin{array}{l}\text { Ras- } \\
\text { mus- } \\
\text { sen } \\
\text { et al, } \\
2003 \\
(15)\end{array}$ & $\begin{array}{l}\text { Farms or } \\
\text { farmers }\end{array}$ & $\begin{array}{l}\text { One-day safety course } \\
\text { conducted by occupa- } \\
\text { tional physician and } \\
\text { psychologist; farm } \\
\text { safety check before and } \\
\text { after course conducted } \\
\text { by farm safety specialist, } \\
\text { duration about half day } \\
\text { with verbal feedback and } \\
\text { advice }\end{array}$ & $\begin{array}{l}\text { Group discussion, presentation } \\
\text { by a seriously injured farmer } \\
\text { during the 1-day safety } \\
\text { course }\end{array}$ & $\begin{array}{l}\text { Written report from the farm safety } \\
\text { check; written material and videotapes } \\
\text { to those not able to participate } \\
\text { in the course }\end{array}$ & . \\
\hline $\begin{array}{l}\text { Rauti- } \\
\text { ainen } \\
\text { et al, } \\
2004 \\
(16)\end{array}$ & $\begin{array}{l}\text { Farms or } \\
\text { farmers }\end{array}$ & $\begin{array}{l}\text { Annual health screening } \\
\text { by trained nurse with } \\
\text { one-on-one discussion } \\
\text { regarding specific health } \\
\text { concerns and proper } \\
\text { use of personal protec- } \\
\text { tive equipment; annual } \\
\text { on-farm safety review } \\
\text { by trained farm safety } \\
\text { consultant (local farmer) } \\
\text { with discussion of haz- } \\
\text { ard removal and safe } \\
\text { work methods; } \\
\text { informational meetings } \\
\text { and focus groups to } \\
\text { discuss aspects of the } \\
\text { program }\end{array}$ & $\begin{array}{l}\text { Other participants in the infor- } \\
\text { mational meetings and focus } \\
\text { groups }\end{array}$ & . & $\begin{array}{l}\text { USD } 200 \text { each year paid to } \\
\text { participating intervention } \\
\text { farmer }\end{array}$ \\
\hline
\end{tabular}

a Two of the studies had two intervention groups (standard and enhanced group) and a control group. Only one of the intervention groups could be selected for the meta-analysis; the selected group was the one that was thought to have received a more extensive intervention.

requiring rollover protective structures or safety cabins on all tractors, there was no immediate reduction in injuries, and the trend over time showed an increase both for all injuries (effect size $0.21,95 \%$ CI $0.00-0.41$ ) and for fatal injuries (effect size $0.33,95 \%$ CI $0.15-0.50$ ) (14). 


\section{Discussion}

\section{Summary of the main conclusions}

We found no evidence in the meta-analyses to suggest that educational interventions had an injury-reducing effect. In two separate single studies, the introduction of insurance discounts reduced the level, but not the trend of injuries, and a legislative ban of endosulfan improved the trend for pesticide poisonings, but it was
Table 3. Methodological validity of the randomized controlled trials analyzed with the Downs \& Black (6) checklist.

\begin{tabular}{lcccc}
\hline Study & $\begin{array}{c}\text { Reporting } \\
\text { validity } \\
(\mathrm{N}=10)\end{array}$ & $\begin{array}{c}\text { External } \\
\text { validity } \\
(\mathrm{N}=3)\end{array}$ & $\begin{array}{c}\text { Internal } \\
\text { validity } \\
(\mathrm{N}=13)\end{array}$ & $\begin{array}{c}\text { Total } \\
(\mathrm{N}=26)\end{array}$ \\
\hline Gadomski et al, 2006 (8) & 9 & 2 & 8 & 19 \\
Lee et al, 2004 (9) & 8 & 1 & 5 & 14 \\
Pekkarinen et al, 1994 (11) & 8 & 2 & 5 & 15 \\
Rasmussen et al, 2003 (15) & 9 & 1 & 8 & 18 \\
Rautiainen et al, 2004 (16) & 7 & 1 & 8 & 16 \\
\hline
\end{tabular}

\begin{tabular}{|c|c|c|c|c|c|}
\hline Study or Subgroup & Effect Size & SE & Weight & $\begin{array}{l}\text { Effect Size } \\
\text { IV, Fixed, 95\% CI }\end{array}$ & $\begin{array}{c}\text { Effect Size } \\
\text { IV, Fixed, 95\% CI }\end{array}$ \\
\hline Pekkarinen 1994 & 0.0337 & 0.0997 & $65.2 \%$ & $0.03[-0.16,0.23]$ & \\
\hline Rasmussen 2003 & -0.0488 & 0.1747 & $21.2 \%$ & $-0.05[-0.39,0.2$ & \\
\hline Rautiainen 2004 & 0.0476 & 0.2183 & $13.6 \%$ & $0.05[-0.38,0.48]$ & \\
\hline Total $(95 \% \mathrm{Cl})$ & & & $100.0 \%$ & $0.02[-0.14,0.18]$ & \\
\hline \multicolumn{6}{|c|}{ 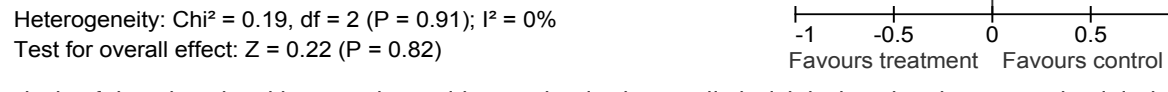 } \\
\hline
\end{tabular}

Figure 1. Meta-analysis of the educational interventions with a randomized controlled trial design aimed at preventing injuries among adults. The outcomes have been reported as effect sizes and standard errors (SE). (95\% Cl $=95 \%$ confidence interval)

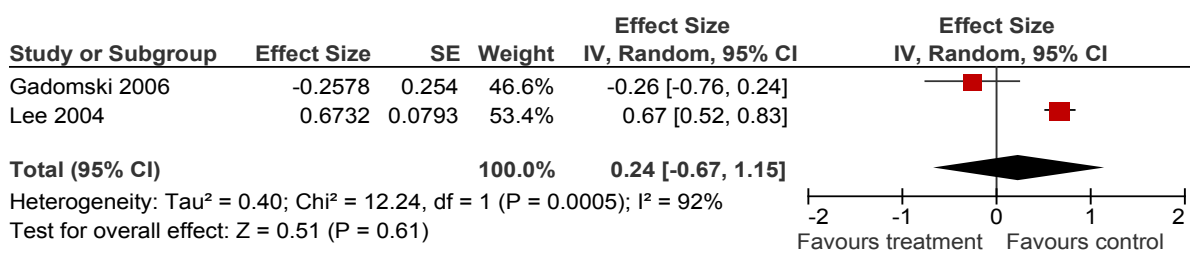

Figure 2. Meta-analysis of the educational interventions with a randomized controlled trial design aimed at preventing injuries among children and adolescents. The outcomes have been reported as effect sizes and standard errors (SE). ( $95 \% \mathrm{Cl}=95 \%$ confidence interval)

Table 4. Results of the reeanalysis of studies involving interrupted time series . (SD = standard deviation, $\mathrm{SE}=$ standard error)

\begin{tabular}{|c|c|c|c|c|c|c|c|c|c|}
\hline \multirow[t]{2}{*}{ Study } & \multicolumn{2}{|c|}{ Preintervention level } & \multicolumn{2}{|c|}{ Change in level } & \multicolumn{2}{|c|}{ Preintervention trend } & \multicolumn{2}{|c|}{ Change in trend } & \multirow[t]{2}{*}{ Autocorrelation } \\
\hline & Mean & SD & Mean & SE & Mean & SE & Mean & SE & \\
\hline Rautiainen, 2005 (17) & 51.80 & 2.43 & -6.51 & 1.39 & 0.31 & 0.23 & -0.54 & 0.32 & -0.54 \\
\hline Roberts et al, 2003 (18) & 11.14 & 10.75 & 23.64 & 6.78 & 4.38 & 1.00 & -23.10 & 2.69 & -0.34 \\
\hline \multicolumn{10}{|l|}{ Springfeldt 1993 (14) } \\
\hline \multicolumn{10}{|c|}{ Data from 1957 tractors to 1964} \\
\hline Injuries & 23.17 & 3.69 & 8.42 & 6.56 & -0.79 & 3.95 & -1.00 & 4.07 & 0.14 \\
\hline Fatalities & 16.43 & 2.48 & -3.80 & 7.84 & 3.55 & 5.03 & -5.75 & 4.94 & -0.75 \\
\hline \multicolumn{10}{|c|}{ Data from 1960 tractors to 1969} \\
\hline Injuries & 23.28 & 4.36 & 3.41 & 4.77 & -2.62 & 1.11 & -0.46 & 1.48 & -0.49 \\
\hline Fatalities & 9.92 & 4.28 & 0.84 & 2.52 & -2.12 & 0.59 & 1.76 & 0.78 & -0.53 \\
\hline \multicolumn{10}{|c|}{ Data from 1966 tractors to 1982} \\
\hline Injuries & 12.38 & 7.76 & 7.00 & 2.91 & -4.72 & 0.99 & 4.47 & 0.99 & -0.37 \\
\hline Fatalities & 0.023 & 1.01 & -0.79 & 1.40 & 0.53 & 0.47 & -0.86 & 0.48 & 0.02 \\
\hline \multicolumn{10}{|c|}{ Data from 1974 tractors to 1990} \\
\hline Injuries & 4.47 & 1.79 & -0.21 & 0.97 & -0.46 & 0.12 & 0.43 & 0.19 & -0.20 \\
\hline Fatalities & 1.33 & 1.42 & 1.16 & 0.67 & -0.48 & 0.09 & 0.43 & 0.13 & -0.12 \\
\hline
\end{tabular}


not associated with a change in poisonings in the short term. In another study, new regulations requiring technical improvements on tractors showed a favorable effect on injuries only in 1 of 16 specific trend analyses.

\section{Strength and limitations}

We included only studies with robust study designs, and we were able to combine the results of similar intervention studies in the meta-analyses. This procedure increased the power to detect the effect of these interventions. The inclusion of only the studies that measured injuries as an outcome is another strength of our review. It increased the quality of the evidence because the link between knowledge and attitudes and injury outcomes has not been strongly established (19).

We conducted a very sensitive search and are confident that all of the studies that met our inclusion criteria were identified. In addition we had all non-English language abstracts read and interpreted by a person with appropriate language skills.

We included interrupted time-series studies, which are difficult to interpret in regard to the effect of the intervention. For instance, regulation may have an immediate effect in some cases or a delayed effect in others if the intervention initiates gradual changes. In some of the reviewed studies, the authors drew conclusions regarding the intervention effects on the basis of visual observation only. By statistically analyzing both immediate and progressive outcomes, our review provides a more robust assessment of the intervention impact in interrupted time-series studies.

We found no evaluations of engineering interventions, except the Swedish intervention with rollover protective structures, which we considered under regulatory interventions. The unexpected direction of some of our findings in relation to such structures is inconsistent with the prevailing view that engineering interventions are generally considered the most effective. Improvement in the design of machines, environments, and systems is preferable to attempts to change attitudes and behavior (20). Furthermore, risk compensation, among other confounding factors, may occur as a result of safer design. Therefore, further evaluations of such engineering interventions are needed.

Altogether $90 \%$ of the farming population live in Asia and Sub-Saharan Africa. However, all but one of the studies we found was based on data from industrialized countries (18). Most of our conclusions therefore may not be generalizable to developing countries, as the settings are so different.

\section{Interpretation}

The educational interventions in the reviewed studies may have been expected to show some effect, as they were comprised of combinations of different elements and engaged the study participants in different ways. However, the effect sizes were small and not statistically significant. Similarly, the meta-analysis showed no effect, and the $95 \%$ confidence interval was narrow, indicating good precision. Only the study of financial incentives showed an effect on injury rates (17). However, due to financial incentives, it is possible that farmers underreported injuries.

Our negative findings are consistent with the results of other studies evaluating the impact of educational interventions alone on injury outcomes (21). These findings indicate that educational interventions are not adequate to bring about change, unless combined with incentives such as financial benefits or legislative requirements.

Pesticides constitute a serious health hazard to farmers, especially in developing countries. However, our review found only one study that addressed acute poisoning risk. This time series study showed that banning a toxic pesticide had a favorable effect on poisoning fatalities in the long term, and it did not lead to an illegal and more dangerous use of pesticides.

The Swedish study on rollover protective structures (14) is frequently cited as strong evidence for the effectiveness of such structures (22). An explanation for our contradictory findings could be that, even if the legislative changes were introduced to start on a certain date, it appears there were no clear interruptive effects since the percentage of tractors with rollover protective structures increased gradually, without major peaks. By the end of the study period, nearly $100 \%$ of tractors had such structures. It is interesting to note that the fatalities decreased to near zero early, much before the percentage of rollover protective structures reached full compliance. This finding appears to differ from experience in the United States, where about $60 \%$ of all tractors are currently equipped with rollover protective structures, but overturn fatalities are still common, about 100 per year $(23,24)$. Another limitation of the study was the fact that there were only two time points before the first legislation on rollover protective structures came into force in 1959, and it was therefore difficult to evaluate that intervention. Yet this initial legislation may have been the most important, initiating the steady increase in the percentage of tractors with rollover protective structures and a decrease in injury rates, particularly in the early years of the observation period.

\section{Quality of the evidence}

It is important to note that at least some of the included studies were designed as a randomized controlled study, although it is often argued that such a design is difficult or impossible to apply in occupational health settings. 
However, it remains difficult to perform high-quality studies, as the blinding of participants and providers is virtually impossible in educational interventions. None of the included studies scored more than $70 \%$ of the possible score on the quality checklists. However, compared with the quality of evidence included in previous reviews, there was notable improvement in the quality of the studies (4).

\section{Other reviews}

Other reviews of interventions to prevent childhood farm injuries concluded that there was insufficient evidence to draw firm conclusions on their effectiveness $(25,26)$. Three other reviews on general farm safety interventions $(4,27)$, and educational interventions (28) using less strict inclusion criteria than we used, also concluded that there was no evidence available. We were able to include several randomized controlled trials and interrupted time-series studies not included in the previous reviews. This difference enabled us to conduct meta-analyses and draw conclusions on educational interventions from a larger number of studies.

Another review on interventions to reduce pesticide poisonings concluded that exposures had been reduced but that there was a lack of evidence about whether concomitant poisonings had decreased (29). Our review found only one pesticide-related study that evaluated legislative intervention.

In general, this review revealed that only a small number of high-quality studies have been conducted in this area, providing a limited evidence base from which to inform prevention programs. It is clear that continued significant efforts are needed to develop and evaluate farm injury interventions.

\section{Implications for practice}

This review found no evidence supporting the widespread use of educational interventions alone. However, there is likely a place for educational components within multifaceted interventions. The use of financial incentives could be effective but should be studied further before more extensive implementation can be recommended. The banning of endosulfan lowered the rate of fatal pesticide poisonings in one study and should be considered for other countries without such legislation.

\section{Implications for research}

Randomized controlled trials are possible and feasible both at the individual level and at the farm level. More of these studies are needed for evaluating behavioral interventions and interventions to enhance the implementation of engineering interventions. Interrupted time-series studies using administrative databases are feasible for studying the effects of interventions, particularly those at the society level (including legislative changes). Further studies should address the expected impact of legislation on the time series of injury rates. Finally, studies are needed that address farm safety problems in developing countries.

\section{Acknowledgments}

The source for external support was the Commonwealth of Australia, as represented by and acting through the Department of Employment and Workplace Relations. The Office of the Australian Safety and Compensation Council was the direct supporter. Lesley Day was supported by a Senior Research Fellowship from the Australian National Health and Medical Research Council.

Merja Jauhiainen, information specialist at the Institute of Occupational Health, Kuopio, Finland, provided expertise and assistance in the development of the search criteria. The review group co-coordinator, Katharine Ker, provided expertise on the development of injury definitions. The trial search coordinator, Karen Blackhall, assisted with the development of the search strategy. Vasiliy V Vlassov, MD, and Arve Lie, MD, provided help with the assessments of the eligibility of the foreign language articles. Dr CR Ramsay kindly helped with the assessment of the interrupted time-series studies.

\section{References}

1. Earth Trends, the Environmental Information Portal (Agriculture and Food) [Internet]. Washington (DC): World Resources Institute; 2008 [cited 1 April 2006]. Available from: http:// earthtrends.wri.org/searchable_db/index.php?.action=select_ countries \& theme $=8 \&$ variable $\_$ID $=842$.

2. Agriculture and natural resources based industries: general profile [chapter 64]. In: Myers ML, editor. ILO encyclopaedia of occupational health and safety [Internet] Ontario (CA): Canadian Centre for Occupational Health and Safety (CCOHS). [cited 2006 March 14]. Available from: http://www.ilocis.org/en/contilo10.html.

3. International Labour Office (ILO). Facts on agriculture. Geneva: ILO; 2002 [cited 15 June 2006] Available from: http://www.ilo.org/public/english/bureau/inf/download/wssd/pdf/agriculture.pdf.

4. DeRoo LA, Rautiainen RH. A systematic review of farm safety interventions. Am J Prev Med. 2000; 18(4 suppl):51-62.

5. Rautiainen RH, Lehtola MM, Day LM, Schonstein E, Suutarinen J, Salminen $\mathrm{S}$, et al. Interventions for preventing injuries in the agricultural industry [CD-ROM]. Oxford (United Kingdom): Cochrane database of systematic reviews; 2008. Number 1, CD006398.

6. Downs SH, Black N. The feasibility of creating a checklist 
for the assessment of the methodological quality both of randomised and non-randomised studies of health care interventions. J Epidemiol Community Health. 1998;52(6):377-84.

7. Ramsay CR, Matowe L, Grilli R, Grimshaw JM, Thomas RE. Interrupted time series designs in health technology assessment: lessons from two systematic reviews of behavior change strategies. Int J Technol Assess Health Care. 2003;19(4):61323.

8. Gadomski A, Ackerman S, Burdick P, Jenkins P. Efficacy of the North American guidelines for children's agricultural tasks in reducing childhood agricultural injuries. Am J Public Health. 2006;96(4):722-7.

9. Lee BC, Westaby JD, Berg RL. Impact of a national rural youth health and safety initiative: results from a randomized controlled trial. Am J Public Health. 2004;94(10):1743-9.

10. Higgins JPT, Green S, editors. Cochrane handbook of systematic reviews of interventions: version 4.2.6. [Internet; updated September 2006; cited 10 October 2008]. Oxford (United Kingdom): The Cochrane Collaboration; 2005. Available from: http://www.cochrane.org/resources/handbook/ Handbook4.2.6Sep2006.pdf.

11. Pekkarinen A, Anttonen H, Pramila S. Accident prevention in reindeer herding work. Arctic. 1994;47(2):124-7.

12. Ramsay CR, Grimshaw JM, Grilli R. Robust methods for reanalysis of interrupted time series designs for inclusion in systematic reviews [poster presentation (session A); Internet; cited 2006 May 30]. In: 9th International Cochrane Colloquium, Lyon, France, 9-13 October 2001. London: BioMed Central; 2001. Available from: http://www.biomedcentral. com/abstracts/COCHRANE/1/pa006/.

13. Vidanapathirana J. Mass media interventions for promoting HIV testing [CD-ROM]. Cochrane database of systematic reviews [CD-ROM]. Oxford (United Kingdom): Cochrane database of systematic reviews; 2005. Number 3, CD004775.

14. Springfeldt B. Effects of occupational safety rules and measures with special regard to injuries. Sweden: The Royal Institute of Technology, Department of Work Science; 1993.

15. Rasmussen K, Carstensen O, Lauritsen JM, Glasscock DJ, Hansen ON, Jensen UF. Prevention of farm injuries in Denmark. Scand J Work Environ Health. 2003;29(4):288-96.

16. Rautiainen RH, Lange JL, Hodne CJ, Schneiders S, Donham KJ. Injuries in the Iowa Certified Safe Farm Study. J Agric Saf Health. 2004;10(1):51-63.

17. Rautiainen RH. Effects of premium discount on workers' compensation claims in agriculture in Finland. Am J Ind Med. 2005;48(2):100-9.

18. Roberts DM, Karunarathna A, Buckley NA, Manuweera G, Sheriff MH, Eddleston M. Influence of pesticide regulation on acute poisoning deaths in Sri Lanka. Bull World Health Organ. 2003;81(11):789-98.

19. Clarke $\mathrm{S}$. The relationship between safety climate and safety performance: a meta-analytic review. J Occup Health Psychol. 2006;11(4):315-27.

20. Heidt H, Groh G. Schwerpunkte landwirtschaftlicher Arbeitsunfälle und Möglichkeiten zu ihrer Verhutung [Common agricultural occupational injuries and possibilities for prevention]. Landtechnik. 1984;39:35-40.

21. Duperrex O. Safety education of pedestrians for injury prevention [CD-ROM]. Oxford (United Kingdom): Cochrane database of systematic reviews; 2002. Number 2, CD001531.

22. Reynolds SJ, Groves W. Effectiveness of roll-over protective structures in reducing farm tractor fatalities. Am J Prev Med. 2000;18(4S):63-69.

23. Myers ML, Cole HP, Westneat SC. Projected incidence and cost of tractor overturn-related injuries in the United States. J Agric Saf Health. 2008;14(1):93-103.

24. National Agricultural Statistics Service (NASS). 2006 Farm and ranch safety survey [Internet]. Washington (DC): NASS; 2008 [cited 2008 March 14]. Available from: http://usda.mannlib.cornell.edu/usda/current/FarmSafe/FarmSafe-01-17-2008. pdf.

25. Hartling L, Brison RJ, Crumley ET, Klassen TP, Pickett W. A systematic review of interventions to prevent childhood farm injuries. Pediatrics. 2004;114(4):483-96.

26. Reed DB, Claunch DT. Nonfatal farm injury incidence and disability to children: a systematic review. Am J Prev Med. 2000;18(4S):70-9.

27. McCurdy SA, Carroll DJ. Agricultural injury. Am J Ind Med. 2000;38(4):463-80.

28. Murphy DJ, Kiernan NE, Chapman LJ. An occupational health and safety intervention research agenda for production agriculture: does safety education work? Am J Ind Med. 1996;29(4):392-6.

29. Keifer MC. Effectiveness of interventions in reducing pesticide overexposure and poisonings. Am J Prev Med. 2000;18(4 suppl 1):80-9.

Received for publication: 8 May 2008 